\title{
Ethno-confessional Relations in Modern Russia: Formation and Epistemological Status
}

\begin{abstract}
In the modern social philosophy and ethnic sociology the different trend has become the dominant according to which nationality is the product of personality self-identification, that is a person subjective self-determination. With this approach, the criterion of nationality, as we can see, is not a traditional factor of kinship, and one of the elements of human self-consciousness. Today more and more popular is a synthetic concept of nationality. This means that the term "nationality" should, on the one hand, imply membership of a particular social and ethnic community - nation, nationality, ethnic group - and, on the other hand, be the result of subjective awareness, self-identification with this group. Socio-ethnic community, including tribe, nationality, nation, exists objectively and has such essential features as the economy, territory, way of life, vital activity, has specific transcendental characteristics (relationship to the world, mentality, ethnonym (self-designation), etc.).

Keywords: social philosophy, ethnic sociology, self-identification, confessional specificity, ethnoconfessional relations, nationalism, ethnicization, ethnic group, Russian Orthodox church, "Islamic banking".
\end{abstract}

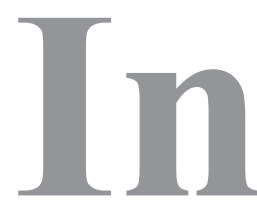
the modern social philosophy and ethnic sociology the different trend has become the dominant according to which nationality is the product of personality self-identification, that is a person ${ }^{1}$ subjective self-determination. With this approach, the criterion of nationality, as we

\footnotetext{
${ }^{1}$ Marody M. On functions of religion in molding the national identity of poles // Intern. J. of sociology._ Annonk, 2005-2006.N 4.- P. 49-68.
}

can see, is not a traditional factor of kinship, and one of the elements of human self-consciousness.

Today more and more popular is a synthetic concept of nationality. This means that the term "nationality" should, on the one hand, imply membership of a particular social and ethnic community - nation, nationality, ethnic group and, on the other hand, be the result of subjective awareness, self-identification with this group.

Socio-ethnic community, including tribe, nationality, nation, exists objectively and has such

RAZIN Alexander Sergeevich - PhD in Philosophy, Lecturer, Chair of Philosophy, History and Political Science, Federal State Budgetary Educational Institution of Higher Professional Education Volgograd State Agrarian University. 400002. Russia, Volgograd, Universitetskiy prospekt, 26. [razin-1978@yandex.ru] 
essential features as the economy, territory, way of life, vital activity, has specific transcendental characteristics (relationship to the world, mentality, ethnonym (self-designation), etc.).

Different socio-ethnic groups presence in the state gives rise to a national relations that exist in three forms:

> intra-national connections;

$>$ relationships between socio-ethnic communities;

$>$ interpersonal relationships of various nationalities.

The concept "religious' refers to individuals and communities, including ethnic, characterized by the presence of the religious consciousness. Just ethnic groups are the subjects of religious activity and religious relations. It should be borne in mind that modern science distinguishes between "religious and nonreligious activities' and 'religious and nonreligious relations' with respect to religious subjects ${ }^{1}$. Religious activities - outcultic and cultic - is religious activities of individuals, groups, institutions and organizations, which is expressed in the development of doctrine and in its propaganda, in training of clergy, in various forms of religious acts.

As a rule, this kind of activity does not act outside the religious component (i.e., inter-religious) relations. Typically, religious subjects of nonreligious activities - political, economic, in its regard act predominantly. Non-religious activities often takes a religious coloring ("religious politics", "Islamic banking", etc.), or interpretation, but in its objective content, it is in fact non-religious activities. The same is true with religious relations.

Religion and ethnicity are essential components of the modern social system. Therefore the study of ethnic and religious relations as complex multifunctional public entities, as well as the study of their role in the society's dynamics, the specific interpenetration and interaction is of considerable scientific interest. The analysis of the relationship of religion and ethnic group requires special at-

\footnotetext{
${ }^{1}$ Razin A.S. Formation of ethnic and religious relations in Russian society: political and philosophical analysis / / Politics and Society.-2013. Number 2, p.189-199.
}

tention to the existing categorical system. First of all, it is related to concepts such as "confession", "confessional specificity", "ethnic specificity."

As it is known, confession (from Lat. Confessio) - recognition, cred. According to the founder of ethnic and religious issues in the domestic science A. N. Ipatov, confession can be considered as a religious movement that emerged in a particular religious system in the socio-historical development of society, specifically combining doctrinal, religious, organizational and structural features of the system ${ }^{2}$. So is Christianity, which is characterized by an extremely multiconfessionality. It includes Catholic, Orthodox, Lutheran, Anglican, Calvinism, Mennonitism, Baptism. Today, many of these churches are ethnically distinct character, they acquired as a result of long-term ethno-religious cooperation ${ }^{3}$.

As it is known, confessional and national identity is carried out in the minds of people on this basis, which is expressed in the form of a dichotomous scheme "Pole-Catholic", "RussianOrthodox." For the "confessions' a good level of self-awareness, organization and institutionalization, with its center of dogma is characteristic.

In this direction, the study of contemporary Canadian scientist M. Bouchard is interesting ${ }^{4}$. Analyzing the written monuments of medieval Russia, in particular: the Psalms, "The Tale of Bygone Years", "Sermon on Law and Grace" by Metropolitan Hilarion, M. Bouchard comes to the following conclusions:

$>$ Russian nation owes its form not rather the state, as it is considered by most scholars, but the Orthodox Church;

$>$ the oldest written religious monuments, especially the Psalms, clearly show that the origins of Russian nation lies in the Orthodox faith.

Orthodoxy was one of the unifying and creative factors that served as the "transformation"

\footnotetext{
${ }^{2}$ Ipatov A. N. Orthodoxy and Russian culture.- M.: 1985. P.22.

${ }^{3}$ Dostoyan I. S., Karasev A.V. The Orthodox Church and the forming of the Serbian nation.-M., 1999.- P. 138.

${ }^{4}$ Michel Bouchard. Orthodoxy as the ideological basis of the formation of the Russian nation / / Ethnographic Review. 2002. № 4, p.139-149.
} 
of Kievan Russia population in one Russian people. In the early stages of the Russian nation development it was united Orthodox faith which become the paradigm that underpinned the national consciousness of the Russian people. The Baptism of Russia should be seen as the starting point of a formal reference of becoming Russia. Perhaps here we must look for the origins of Russian ethnicity and national identity.

It's no secret that ethnic and religious communities have strong cultural specificity. However, they amount neither meaningful nor chronologically. Ethnic differences, as well as traditional differences in religion, according to the American anthropologist Roger Brubaker are universal to mankind in every historical period of its existence ${ }^{1}$.

The study of Religions of the Ancient Orient and antiquity, such as the Egyptian, Babylonian, Syrian, Greek, reveals that they have a close connection between religious and ethnic characteristics. Similar were not only ethnic characteristics, but also the sacrifices and processions, compliance with the regulations regarding meals and ablutions. Only in this way it was possible to prove that they belong to a particular religion ${ }^{2}$.

The relationship of ethnic specificity with religious manifested in that an individual belonging to a particular religion acted as his ethnicity. The results of the interaction of religion and the specifics of a particular ethnic group were essentially ethnoconfessional. Social maturity ethnic group (completion of the formation of a community or group as ethnic) is characterized by the creation of their own religious value system.

Considering the relation of religion and ethnos, with the social processes that underlie its formation and change, it should be noted that religion, being coupled with these processes, plays at the same time, the dual as etnodividing and ethnic integration role. This has always been two ways. However, in many situations, religion, due to the close connec-

\footnotetext{
${ }^{1}$ Brubaker R. Ethnicity as cognition // Theory a. society.Dordrecht, 2004.- N 33.- P.31-64.

${ }^{2}$ Firth R. Religion in social reality // Elements of social organization.- L.: Watts \& Co., 1951.- P.215-250.
}

tion with the dynamic and moving elements of the mass psychology encircling strengthened ties within the ethnic group and thus opposed the assimilation of its conquerors. The most striking example is the history of the Jewish people, who are in the Diaspora for about two thousand years, thanks to Judaism, retained their language, traditions, identity, cult ${ }^{3}$.

Thus, the key trends of shaping social relations between religion and ethnos appear in the interaction of confessional and ethnic specificity.

The first trend - a "confessionalization" ethnic phenomena and properties, in which a number of culture features and way of life for a long interaction are soaked in a cult, become its constituent elements. French philosopher and sociologist Emile Durkheim emphasized in the early twentieth century the exceptional importance of religion in the creation and strengthening of ethnic unity. He noted that religion sanctifies the fundamental social relations of society, which makes the integrity of social groups. What is sacred, living not so much in formal laws, but in the soul and the conscience of a living person ${ }^{4}$.

Analyzing the ideas of Durkheim, the Russian scientist D. V. Pivovarov notes that religion compensates for the shortcomings of rational science, gives his understanding of the meaning and purpose of life, society, nation, class, man. "Religion - continues Pivovarov — has a special spiritual and practical relationship between people based on a sacred regard to such values (ideas, processes, activities, people, things, the world in general), which are recognized as the most important for believers to strengthen the unity of their community"s.

According to another scientist, V.I. Kornev: "Religion is not only gives specific socio-cultural space, but also forms the psychology of the space community, in other words, it is religion that

\footnotetext{
${ }^{3}$ The role of religion in the formation of the South Slavic nations.M., 1999.- 264 p.

${ }^{4}$. E. Durkheim. Sociology of Religion and the theory of knowledge / / Religion and Society.-M-1996. P. 113.

${ }^{5}$ Pivovarov D. V. Religion: the relationship natural-centric and sociocentric forms / / Religion, Society and State in the twentieth century. Moscow, 1991. P.102.
} 
creates psycosociocultural space-time, which is able to accommodate many nations and ethnic groups".

The second trend is "ethnicization" of religious phenomena and the cult of the individual components of the complex, (especially of the rituals, customs and religious traditions), through its penetration into national forms of social life through the merger with the popular beliefs that ethnogenetic. Faith-based phenomena assume the character of ethnic phenomena, ethnically colored. It should be noted that the denomination "is ethnicized" only when its members live compactly. This is where religious differences penetrate deep into the life and faith, if it was perceived ("prozeletically"), has inherited at least a few generations ${ }^{2}$.

These are the two major trends of formation of relationship between religion and ethnic group. As a result of their actions folding connections between confession and a number of features of an ethnic community (traditional forms of economy and way of life, culture and consumer specifics, language, ethnic identity, etc.) affect the fusion of religion and the social experience of people on the formation of nations and in the future nations. We point out that all the religions of the world are cosmopolitan, do not recognize the existence of nations based on ethnicity. For example, Islam recognizes only the "ummah" i.e. community of the faithful, then for Christianity "there is neither Hellene nor Jew"3.)

According to L.N. Mitrokhin's opinion, in particular national culture, religion is not just a shell, or "external ideological formation", and "special science of life", which is deeply rooted in the economic activities of the people, threading their attitude 4 . Religious ideas and processes in the national consciousness are characterized by many

\footnotetext{
${ }^{1}$ Kornev V.I. The phenomenon of religion / / Asia and Africa nowadays.-1994.— № 1. p. 33.

${ }^{2}$ Schnee W. Nationalism: A review of the literature // J. of polit. a. milit. sociology.- New Brunswick, 2001.- N 1.- P. 1-18.

${ }^{3}$ Mirsky G. Ethnicity, religion, nationalism / / Asia and Africa today. 1994. Number 2. P.4.

${ }^{4}$ Mitrokhin L. N. Philosophy of Religion: New Perspectives / / Issues of philosophy.-2003.— № 8. P.23.
}

similar feelings, emotions, moods, emotional state of people. They have the ability to overlap each other, forming a common, increasing with this guide practical expression of sensual and psychological state.

Thus, ethnoconfessional relations are, on the one hand, the shape of the relationship of believers to hypostatize beings, properties, relations (especially to God), on the other hand - the form of the relationship of believers with each other, both within their communities and denominations, and out of them. As a part of the latter type of relations, representatives of different religions are increasingly included in the scope of non-religious relations, they are actively discussing the issues of war and peace, economics and social issues. The involvement of religious actors in the data for objective cannot be attributed to the sphere of religious relations, although subjectively in this relationship may have been pouring a specific religious meaning.

Summarizing, we can say that the ethnic and religious relations are a complex interaction between ethnic communities and their institutions on the one hand, and the followers of different religions and within their existing denominations, as well as the subjects of these religions and faiths (religious groups, governments religious associations, ministers the church), on the other hand.

In our field, there are several different definitions regarding "ethnic and religious communities." For example, the V. N. Raguzin gives it a deeper meaning when he writes that "... it is a special type of social community of people, decorated with religious way of life, ethnic identity. It acts as a religious community, but in specific socio-historical context plays a determinant of ethnic features" 5 .

It should be emphasized that the coincidence of ethnicity and religion does not mean their identities or inseparability. These concepts are actually beyond identification, since most of the important characteristics and the characteristics of the ethnic group cannot be attached

\footnotetext{
${ }^{5}$ Raguzin V.N. On the edge of Russian geopolitics.- Moscow: 1999.p.74.
} 
to the religious community. As S. I. Brook, N. N. Cheboksarov, Ya.V. Chesnov notice ethnic and religious communities "cannot be considered as nations or ethnic groups in the truest sense of the word. To form an ethnic community of any order, it is necessary that it has the characteristic features of the material and spiritual culture, expressed in a particular common language. Therefore, the third, a very important part of any community, a kind of resultant of all ethnogenetic factors, ethnic identity is"1.

As the British sociologist M.F. Bendle says we are not dealing with the identification as such, but with the substitution of its communication taking place between religious and ethnic identity, which (tie) explains why, for example, "Pole-Catholic" distinguishes itself from the "Lithuanian-Catholic", "Russian-orthodox" from "Bulgarian-Orthodox", "Uzbek Muslim" from the "Kazakh-Muslim", "Belarusian Catholic" from the "BelarusianOrthodox". In its turn, this relationship itself, as it has historically transient, denies any identification of religion and nationality ${ }^{2}$.

The believers that make up a particular community, outside the walls of the church are not only the actual believers, members of a religious community. In the world they are, above all, simply citizens, hard workers, “economic entities' that have a variety of terrestrial problems of social, economic, political and cultural nature. Along with this, they are different ethnosocial communities who have a certain relationship with each other.

In each of these communities a kind of historical social relations developed and social structures were formed. In different ways they proceeded ethnoforming processes. And they all have similar features and characteristics. While their formation, there has been a direct impact on specific faiths institutional forms of data structures and social behavior of members of ethnic communities. Naturally, the ethnoforming processes imposed their features on the specified

\footnotetext{
${ }^{1}$ Brooke S.I., Cheboksarov N. N., Chesnov Ya.V. Problems of ethnic development of foreign Asia / / Questions of history.1969.— № 1.- P. 99.

2 Bendle M.F. The crisis of "identity" in high modernity // Brit. J. of sociology.- L., 2002.— № 1.
}

confessions ${ }^{3}$. Indeed, ethnic and confessional community legitimately are qualified as a specific type of social community of people decorated with religious way of life, ethnic identity which acts as the religious, the host in specific sociohistorical conditions of the determinant function of ethnicity ${ }^{4}$.

According to the modern researcher of ethnic and religious perspectives S.P. Petrenko, ethnic and religious communities share the following distinctive features ${ }^{5}$ :

$>$ identity (ethnic or confessional);

$>$ name and self-designation - endoetnonim and endoconfessionim;

$>$ sense of solidarity;

$>$ common cultural traditions;

$>$ endogamy.

Note also that in the Soviet literature in recent years the concept of "inter-religious relations' is increasingly used and (often synonymous with the relationship, although in strictly scientific sense, this is not true) "interfaith relations." Indeed, in the strict sense of the word the term "interfaith relations' should be used with regard to the relationship between the followers of different religions and their institutions, such as Christianity, Islam, Buddhism, while the "interfaith relations' should be characterized by relations between the followers of specific faiths and institutions within the a religious movement (for example, between the Orthodox, Catholic and Protestant associations). The totality of the above relationship can be fixed in the concept of "religious-confessional relations' proposed by Yu.P. Zuev and N. V. Truseneva ${ }^{6}$. As

\footnotetext{
${ }^{3}$ Amelin V.V. Ethno-confessional relations in the estimates and beliefs of mass consciousness of Orenburg people/ / Journal of Sociology and Social Anthropology. 2002 vol. V.— № 4.- P. 59-85.; Sultangaliyev A. A. Religion and ethnic communities. - Ufa, 1997.- P. 43.; The role of religion in the formation of the South Slavic nations / under edition of I. V. Churkina.-M., 1999.- P. 11.

${ }^{4}$ Razin A.S. On the category of "ethno-confessional" in Social Philosophy / Science. Philosophy. Society. Proceedings of the V Congress of Philosophy of the Russian / A.S. Razin. Volume II.- Novosibirsk, 2009, P. 526.

${ }^{5}$ Petrenko S. P. Confessional community and ethnicity: similarities and differences / / Humanities and social and economic sciences.-2006. - № 12.- P.14-18.

${ }^{6}$ Zuev Yu.P., Truseneva N.V. Religious-confessional relations in modern Russia / / State-Church relations in Russia. 2 vols.—M., 1995.— P.155..
} 
this "synthetic" definition most fully reveal the gist of these complex social relationships.

Along with a marked distinction between inter-religious and inter-confessional relations in the domestic religious studies an expansive interpretation of the latter type of relationship developed. Not only relationship between the denominations and faith-based organizations are included in view of interfaith relations, but also between different religions and their organizations. Accordingly, when we use the term "ethnic and religious relations," we mean a complex interaction between ethnic communities and their institutions ethnophors and followers of different religions and within their existing denominations. They deal with subjects of religions and faiths: religious groups, government religious associations, ministers of churches and religious associations.

Thus, ethnic and religious relations are a complex and actively influencing on the social life of the modern Russia phenomenon. The analysis of this phenomenon allows us to set a specific role of the religious factor and its function in a multinational Russian society, and to identify the relationship between ethno-national and religious consciousness of Russians between their ethnocultural and religious values.

The terms "religious factor", "ethnic factor" in recent years became increasingly commonplace in the social sciences, particularly in religious studies, political science, ethnology, sociology, gradually acquiring the status and quality of the scientific concept that characterizes certain social phenomena. However, in most publications, these concepts are used so far without a clear definition of what causes their ambiguity and difficult to use as a tool of scientific knowledge ${ }^{1}$.

The Latin word factor is in modern translation - "making", "producing". ${ }^{2}$ Initially, it had a very concrete having to man the content. Thus, in "Latin - Russian and Russian-Latin lexicon" by I. Kroneberg (1870), the word factor is inter-

${ }^{1}$ Danakari R. A. Ethnic being: monograph.- Volgograd: Publishing and Printing Complex "Niva", 2007. P. 54.; Denisova G.S., Radovel M.R. Ethnosociology.-Rostov-on-Don:, 2000. P. 236.

${ }^{2}$ Dictionary of foreign words.-18 ed.- M.., 1989.- P. 530. preted as "activist, artist, master of something" (with reference to Catullus) and as "the author, the creator of something "(referring to Ulpian Legal Counsel) $)^{3}$. Subsequently, the content and scope of the term widened, it came to mathematics, which has come to mean "multiplier."

The transition from a general scientific concept of "factor" to the particularly interesting for us concept "religious factor" is the general philosophical and sociological concept of "social factor". S.A. Wojtowicz gives his definition, believing that "the social factor is the driving force behind the development of society, the phenomenon or process causes certain social changes. The basis of this selection is such a relationship of social objects in which some of them (the cause) under certain conditions, the need to have other social objects or their properties (the effect). As a "social factor" human activity warranting ultimately the diversity of social life acts primarily"4.

With regard to religion, it could be a factor that is affecting the state, the change, the development of the religion itself and its constituent elements. These are the factors of the religion evolution, religious consciousness, the factors of stability or change in the religious situation, interfaith relations. They act in situations and processes in society, a country, a region, for which the religion itself or its components, the concrete manifestations are the factors of their condition and dynamics. It is important to take religion as a factor in the spiritual condition of society as a factor of stability or worsening of international relations. It is in the latter case it is legitimate to use the word "religious factor", as there can be traced external influence exerted by the religion.

In the modern scientific literature systemic vision and essence of the concept of "religious factor" is still absent. However, its significance is noticed by many authors, identifying with the

\footnotetext{
${ }^{3}$ Latin-Russian and Russian-Latin lexicon, with a full explanation of the properties and values of each word, with an indication of proper names of ancient geography and mythology, compiled by Ivan Kroneberg. The seventh edition.- M., 1870.- P. 176.

${ }^{4}$ Wojtowicz S. A. Social factor: a sociological guide.- Kiev.1990.- P. 117.
} 
most characteristic features. So, I. N. Sudarev writes: "Russia as a multi-religious country is a unique phenomenon. A particular importance the religious factor has on turning points of its development. It can be used as a great blessing for the country. The main religious confessions at well-formed state policies in this area can be allies in building its modern, powerful and prosperous Russia, they are able to contribute to its internal stability, play a consolidating role in society"1.

Note that at present the majority of religions that exist in Russia, skillfully adapted to the market system, promote a person to an active lifestyle, calling for economic activity because they are based on common sense, practical and rational arguments.

Prominent representatives of all confessions offer to return the economy of its true value, their criticism is directed not so much at economic but on an ethical and cultural system. The economy appears simply as one of the aspects of human life. Following ethical postulate hierarchical Christian churches believe that when production and consumption are the meaning of life, the reason for this lies not in the economy and in easing cultural oblivion morals that society has reduced the whole meaning of life to the production of goods, consumption, comfort and luxury.

Considering Orthodoxy, we note that in today's Russia it has rightfully taken its main and dominant place among all confessional communities. Today, it can play a special role in the sociopolitical stability and consolidation of society. Urging a person to love the world, Orthodoxy at the same time calls on the release of the world in such a way that he puts spiritual interests above the material, understands that no earthly value creation is the main goal of human life, the meaning of his existence. The priority of the spiritual over the material, Christian asceticism and service to the community as a religious setting creates a special relationship between people.

Christianity has developed its own standard of life and activity. Unlike the Protestant utilitari-

${ }^{1}$ The religious factor in contemporary Russia - Moscow, 1996.№ 25, P. 120. anism, it originally came from some other moral criteria that are in demand in the Russian society. In contrast to the Protestant "predestination to salvation" and "justification by faith" ethical norm of orthodoxy is "going to God with the idea of responsibility for it". For the success of Orthodoxy, the success of business, the value of profits brought by never been proof of the moral and ethical justification. The system of values established orthodoxy, the principles of rational activity and its relationship to the man and his work can be the basis of Russia's modernization, to give a positive impulse to the development of small and medium-sized businesses.

Thus, as the religious factor I. N. Sudarev allocates multi-confessional Russia. The object of his influence is the political situation and the expected and desired outcome of this impact - the internal stability of the state and the consolidation of society. The author's instrumental approach to the phenomenon is noteworthy. He believes that the religious factor "can be used" in public policy.

There are still a few positions. The relatively comprehensive definition of the concept study is suggested by A.A. Nurullayev, who writes: "The religious factor is a specific designation of the functioning of the religion and its institutions in the social, economic, political, ethnic, and other relations, all that relates to religion and its institutions as stakeholders in all aspects of public life"2. According to his opinion in the post-totalitarian period, under the conditions of a democratic civil society tends to increase the influence of the religious factor on various aspects of life act here.

In this definition it is essential that as a religious factor the religion itself is not taken but its functioning. It is also important that religious institutions are considered as stakeholders. From this it follows that if a religion as a social phenomenon is potentially always a factor of social life then the turning it into a real factor in the various social processes and social life in general, is through religion, their social functions, through

\footnotetext{
${ }^{2}$ Nurullayev A. A. The religious factor in national processes / / State-Church relations in Russia.- M.: 1994.- part. 1.- P. 100; Volobuev V. A. Islamic fatalism: stereotype or worldviews? / / Philosophy of the economy.—2009.— № 6 (66).— P. 215.
} 
purposeful activities of religious institutions. And as religious institutions and organizations are always on confession, the religious factor in the majority of cases appears as a confessional factor or is generated by the relationship between the confessions.

More over the complete and comprehensive investigation as a confessional factor in domestic science is exposed the Islamic factor. The writings of Islamic studies, orientalists, political scientists, the research of experts on international relations, the term established in the 60-70's of the twentieth century. They were connected with the beginning of the Arab-Israeli conflict, the growth of the national liberation struggle and the process of modernization in many countries of the Islamic world.

In the works of L. A. Bashirov, A. V. Zhuravskov, A.A. Ignatenko, A.I. Ionov, G. M. Kerimov, V.I. Kornev, A. V. Malashenko, G. V. Miloslavsky, E. M. Primakov not only the determination of the Islamic factor is given but its features, structure and content are disclosed. As a factor of social life (international relations, national-liberation struggle, the East-West confrontation, economic and political development of the countries of the Near and Middle East, etc.) are considered in Islam as a whole and its parts and derivatives, doctrine and traditions, the Muslim way of life, Islamic solidarity. The problem of the Islamic factor is considered through the prism of art in the work of M. V. Jordan and R. G. Kuzeev ${ }^{1}$. However, this is an entirely different topic of scientific research.

The native Islamic scholar G. V. Miloslavsky sees a particular feature of the "Islamic factor" in politics, in that it can occur at the same time as a group of elements of foreign policy, due to the inner essence of the state, and among the factors influencing the environment. In other words, considering the role of the "Islamic factor" in the foreign policy of the state, we are facing as a double of his influence, "inside", due to inclusion

\footnotetext{
${ }^{1}$ Jordan M. V., Kuzeev R. G., Chervonnaya S. M. Islam in Eurasia: the modern ethical concepts of Sunni Islam, and their transformation into public consciousness and expression in the arts of the Muslim people of Russia.- M.: 2001. P. 212.
}

of Islam in public institutions, and the "outside"", under the influence of other subjects in international relations ${ }^{2}$.

However, in our public consciousness there is considerable prejudice against a world religion like Islam. Many of the tenets of Islam today can be used to consolidate the society, the modernization of the economy. For example, the doctrine of predestination can be interpreted in terms of brand value. Now it does not hold down the human mind and paralyzes its activity. The idea of divine predestination means that a person in Islam, fighting for his own benefit, also performs the will of Allah. "Most of the individual in achieving practical goals - writes A.A. Guseynov - depends not only on the knowledge that he is fighting for his goals, but from the conviction that it is the real goal"'. The appeal is to the will of God is the recognition of the highest degree of truth.

A huge number of facts from the history and contemporary life of the Muslim people show how closely and organically religious inspiration is combined with vigorous activity in the name of Allah. They refute the judgments of the chilling human life predestination ideas effect. Divine providence is made through the things and events of the earthly world. In order to please Allah, it should act accordingly an objective measure of things that is the best, the most honest properly perform their job.

The observance of the moral precepts of Islam as honesty, truthfulness, justice, rejection of theft, adultery, the injury is the key to the human community. Particular importance should be given to such character traits and virtues that form the personality, contribute to its development and fulfillment. Therefore, in promoting the ideas of Islam should be guided by the common good, which basically has the life experience and common sense, allows you to focus on in the life of personal success, strong-willed and adventurous, active and vigorous activity. It is also important to consider a different attitude to work and labour

\footnotetext{
${ }^{2}$ http://www.newhorizon-slamicbanking.com/index. $\mathrm{cfm} ?=$ breaknew saction.

${ }^{3}$ Gusseynov A. A. The great moralists. M., 1995. P. 141.
} 
activity. Using the tradition of Islam in a multireligious Russia "moral duty" can be built freely in the category and treated it as the ability to work effectively for the benefit of society, family and yourself.

Summarizing, we note that today religion, being an active subsystem of society, with its diverse ties mixed with other components of the social system. It is a real factor in social processes, not only promote its ideas, but also actively pursuing a social mission. Hence it is not by chance that in our theological and philosophical literature in sufficient detail the role and place of ethnic and religious communities in the beginning of modernization of society is widely considered. Analysis of the social functions of religion, the need to identify its universal characteristics becomes imperative.

Success of the modernization of developed countries is primarily due to the fact that they were based not only on their own economic, social and political foundations, but also the specificity and uniqueness of cultural, ethnic and religious characteristics of the society. They meet the internal needs of social development of Western states, allow to solve the pressing social conflicts and build a harmonious and just society.

In the modern conditions of the struggle for social and political stability in the Russian ethnoconfessional factor reflects the unity in diversity of our society. Therefore crucial importance has the use of religions positive potential, their ability to unite communities, collectives, community ("Ummah") through the implementation of various social, economic, labor, economic features, cultural and religious activities, rituals and ceremonies ${ }^{1}$.

Indeed, the long experience of Russian reforms, periodic recurring socio-economic crises, the devaluation of values once again assure us that no social system can get out of the conflict, to begin the revival and development, to achieve success, until no longer rely on its historical and cultural heritage, the spiritual potential of the people.

\section{References}

1. Abdulagatov Z. Russian Orthodox and Muslims: Common Challenges-different views / / Sotsis.-2004.-№

2. - P.153-154. 2. Amelin V.V. Ethno-confessional relations in the estimates and beliefs of mass consciousness of Orenburg people/ / Journal of Sociology and Social Anthropology. 2002 vol. V.—№ 4.- P. 59-85.

3. Andreeva L.A., Ryakhovskiy V.V. Orthodoxy, Protestantism and the strategy of sustainable development of Russia in the beginning of XXI century / / Social Sciences and the present.-2004.-№ 3.- P. 143-153.

4. Brooke S.I., Cheboksarov N.N., Chesnov Ya.V. Problems of ethnic development of foreign Asia / / Questions of history.-1969.—№ 1.- P. 99.

5. Michel Bouchard. Orthodoxy as the ideological basis of the formation of the Russian nation / / Ethnographic Review. 2002. № 4, p.139-149.

6. Wojtowicz S.A. Social factor: a sociological guide.—Kiev._1990.— P. 117.

7. Volobuev V.A. Islamic fatalism: stereotype or worldviews? / / Philosophy of the economy.-2009.—№ 6 (66).— P. 215.

8. Gusseynov A. A. The great moralists. M., 1995. P. 141.

9. Danakari R.A. Ethnic being: monograph._- Volgograd: Publishing and Printing Complex "Niva", 2007. P. 54.

10. Denisova G. S., Radovel M. R. Ethnosociology.—-Rostov-on-Don:, 2000. P. 236.

${ }^{1}$ См. об этом: Разин А.С. Истоки хозяйства (ритуал, обряд, традиция) // Гуманитарные и социально-экономические науки.— 2006.— № 12.— С.105. 
11. Dostoyan I. S., Karasev A. V. The Orthodox Church and the forming of the Serbian nation.M., 1999.- P. 138.

12. Drambyan M. I. Islam as a factor in public life in the Republic of Dagestan / / Ethnographic Review.-2009.-—№ 4.- CP. 51.

13. E. Durkheim. Sociology of Religion and the theory of knowledge / / Religion and Society.M-1996. P. 113.

14. Zuev Yu.P., Truseneva N. V. Religious-confessional relations in modern Russia / / State-Church relations in Russia. 2 vols.- M., 1995.- P.155.

15. Jordan M. V., Kuzeev R. G., Chervonnaya S. M. Islam in Eurasia: the modern ethical concepts of Sunni Islam, and their transformation into public consciousness and expression in the arts of the Muslim people of Russia.- M.: 2001. P. 212.

16. Ipatov A. N. Orthodoxy and Russian culture.-M.: 1985. P.22.

17. Kornev V.I. The phenomenon of religion / / Asia and Africa nowadays.-1994.—№ 1. p. 33.

18. Latin-Russian and Russian-Latin lexicon, with a full explanation of the properties and values of each word, with an indication of proper names of ancient geography and mythology, compiled by Ivan Kroneberg. The seventh edition.- M., 1870.- P. 176.

19. Malashenko A. V. Islam as a factor in restoring the USSR / / Russia and the Muslim World, 1993, № 10, etc.

20. Malyshev D. B. The religious factor in armed conflict today-Moscow: Nauka, 1991.

21. Mirsky G. Ethnicity, religion, nationalism / / Asia and Africa today. 1994. Number 2. P.4.

22. Mitrokhin L. N. Philosophy of Religion: New Perspectives / / Issues of philosophy._-2003.—№ 8. P.23.

23. Nurullayev A.A. The religious factor in national processes / / State-Church relations in Russia.M.: 1994.— part. 1.- P. 100.

24. Omelchenko N. V. Human freedom as a value / / Herald of the Voronezh State University. Series: Philosophy., 2012. Number 1 (7). P 101-111.

25. Petrenko S. P. Confessional community and ethnicity: similarities and differences / / Humanities and social and economic sciences.—2006.—№ 12.— P.14-18.

26. Pivovarov D. V. Religion: the relationship natural-centric and sociocentric forms / / Religion, Society and State in the twentieth century. Moscow, 1991. P.102.

27. Primakov E. M. Islam and social development in the countries of the East. M., 1982.

28. Raguzin V. N. On the edge of Russian geopolitics.- Moscow: 1999.p.74.

29. Razin A. S. The origins of agriculture (ritual, ceremony, tradition) / / Humanities and social and economic sciences.—2006.—№ 12.— P.105.

30. Razin A. S. Formation of ethnic and religious relations in Russian society: political and philosophical analysis / / Politics and Society.—2013. Number 2, p.189-199.

31. Razin A. S. "Islamic banking" as a response to the challenges of the financial crisis / / European Social Science Journal.— Riga-Moscow-2012.—№ 5-p. 375-380.

32. Razin A. S. On the category of "ethno-confessional" in Social Philosophy / Science. Philosophy. Society. Proceedings of the V Congress of Philosophy of the Russian / A. S. Razin. Volume II.- Novosibirsk, 2009, P. 526.

33. The religious factor in contemporary Russia-Moscow, 1996.—№ 25, P. 120.

34. The role of religion in the formation of the South Slavic nations / under edition of I. V. Churkina.M., 1999.- P. 11.

35. The role of religion in the formation of the South Slavic nations.- M.: 1999. - $264 \mathrm{p}$.

36. Dictionary of foreign words.-18 ed.— M.., 1989.- P. 530.

37. Sultangaliyev A.A. Religion and ethnic communities._- Ufa, 1997.— P. 43. 
38. Tsehanskaya K. V. Russia: trends of religiosity in the XX century//Historical Journal_—2000.—№ 5. 39. Bendle M.F. The crisis of "identity" in high modernity // Brit. J. of sociology.— L., 2002.—№ 1.

40. Brubaker R. Ethnicity as cognition // Theory a. society.—Dordrecht, 2004.— N 33.- P.31-64.

41. Firth R. Religion in social reality// Elements of social organization.— L.: Watts \& Co., 1951.— P.215-250.

42. http://www.newhorizon-slamicbanking.com/index.cfm?=breaknew saction.

43. Marody M. On functions of religion in molding the national identity of poles // Intern. J. of sociology.- Annonk, 2005-2006.- N 4.- P. 49-68.

44. Schnee W. Nationalism: A review of the literature // J. of polit. a. milit. sociology.- New Brunswick, 2001.- N 1.- P. 1-18. 